\title{
Behavioural biases in Personal Financial Management and Perceived Financial Satisfaction: The Role of Speculative Risk
} Muhammad Nauman Sadiq ${ }^{1}$, Syed Ali Raza Hamid ${ }^{2}$ Raja Ased Azad Khan ${ }^{1}$

\section{Abstract}

This study is designed to examine the impact of behavioural biases on perceived financial satisfaction and to determine the role of Speculative Risk between these variables. Using structured questionnaire study collects the data from respondents and then analyzes the same by using Reliability Analysis, Factor Analysis and Structural Equation Modeling (SEM) with the help of SPSS and AMOS. The result of study discloses that "Financial self-efficacy" and "Reliance on expert" has significant effect on financial satisfaction, while financial socialization has no significant effect on financial satisfaction. Beside this, study reveals that Speculative risk partially mediates the relationship of "financial self-efficacy" and "reliance on experts" with financial satisfaction. Beside this, moderating role of speculative risk was observed between IV's and DV's. Study reveals that speculative risk significantly moderates the relationship of Reliance on experts and financial satisfaction. This study is important for financial managers, policy makers and individual investors to comprehend the role of behavioural biases in financial decisions and financial satisfaction.

Keywords: Financial self-efficiency; Financial Socialization; financial satisfaction; Speculative Risk

JEL Code: D14, D31, G41

\section{Introduction}

Massive competition in the financial markets provides various investment alternatives to the investors. In this perspective, the personal financial management becomes more complex and the matter of concern for investors. The traditional financial paradigm presumed markets are efficient and publicly disclose all available information to market participants and enable them to make a rational decision (Fama, 1970). However, the new financial paradigm behavioural finance assumed overabundance of products information, and limited information processing ability of investors makes decision making highly complicated and inclines investors to make biased decisions (Pradhan, 2008). In this context, the choice of a financial product is significant (Pompian, 2008). An effective decision-making requires a significant amount of time, cognitive effort, and information processing ability to select the best alternative (Pellerone, 2014). Sahi et al. (2013) stated that effective decisions regarding financial resources not only

${ }^{1} \mathrm{PhD}$ Scholar, Hamdard Institute of Management Sciences, Hamdard University ,Islamabad

${ }^{2}$ Assistant Professor, Hamdard University, Islamabad

Corresponding Author: Nauman_sns22@yahoo.com 
increase financial satisfaction but also improve the quality of life. Study reveals that individuals should be motived to find the financial information and increase the ability to control the emotions that can impact financial management capacities (Atkinson \& Messy, 2011). In this perspective, study reveals that self-efficacy is the effective factor influencing behaviour (Bandura, 1991). Self-efficacy is a personal judgement of an individual to manage, control and influence various aspects of life (Bandura, 1991). However, Behavioural finance reveals that individuals cannot always act rationally in financial decisions (Howard, 2012; Otuteye \& Siddiquee, 2014). To save time and be willing to quick decisions, investors can use behavioural biases (Pellerone, 2015). In behavioural finance literature, numerous behavioural biases are documented that influence investment decision-making (Ritter, 2003; Barberis \& Thaler, 2003; Barber \& Odean, 2001). These biases include overconfidence bias (Szyszka, 2013) reliance on expert bias (Fischer and Gerhardt, 2007) categorisation tendency (Mogilner et al., 2008), the adaptive tendency (Soros, 2003) socially responsible investing bias (Williams, 2007) spouse effect (Sung and Hanna, 1998) self-control bias (Shiller, 2006) financial self-efficacy (Bandura, 1991) and financial socialization (Hira et al., 2013). Studies reveal that Biases are not always bad as it may show the results according to the wish of decision-maker (Olsen, 2007). Sahi, (2017) further elaborates that individuals use biases in the decision to minimize the cost of decision making which leads to the maximization of the utility of individuals.

In finance literature these biases are used to determine their role in investment decisions, however, with the perspective of Pakistan, no prominent study is available which explores the role of these biases as a determinant of financial satisfaction. This study is an attempt to reveal the role of behavioural biases in personal financial management and individuals' financial satisfaction. To end this, the present study uses "financial self-efficacy", "Financial Socialization", and "Reliance on expert" as a proxy for behavioural biases in personal financial management. Financial self-efficacy is an extensive determinant of financial satisfaction (Asebedo \& Payne, 2018). Individuals with greater self-efficacy are confident to handle anxiety and strain persuaded by undesirable events (Asebedo \& Payne, 2018). Persons with a greater level of selfefficacy set higher goals, positively evaluate the task, consider external factors causing threats, and less inclined toward negative psychological factors such as anxiety depression, and stress (Bandura, 1999). Besides its significance in decision making, FSE is also an imperative predictor of financial satisfaction. Asebedo and Payne (2018), reveal that persons with a developed level of financial self-efficacy are better able to manage their financial anxiety and stress and such individuals are more financially satisfied.

Beside this, Reliance on experts is also considered as an important determinant of financial satisfaction. Reliance on experts is a behavioural bias used by low financially literate individuals during financial decision making (Folkman \& Lazarus, 1980). Studies reveal that individuals who use the services of professionals during financial decisions show higher level of financial satisfaction (Xiao et al., 2006). Besides this, individuals who are not financially self-efficient as well as not hiring the services of Sukkur IBA Journal of Management and Business - SIJMB | Vol 8 No. 2 July - December 2021 @ Sukkur IBA University 
financial experts during financial decisions, generally involve parents, peers, and media to make these decisions and this tendency is named as "Financial socialization" (Hira et al., 2013). Financial socialization is also considered as an interpreter of financial satisfaction (Shim et al., 2009).

The present study is trying to explain which behavioural tendency is explaining higher level of financial satisfaction in individuals. Beside this, the study also investigates the role of speculative risk between these variables. Speculative risk reveal "the individual's inclination towards the risk-taking side" (Lampenius \& Zickar, 2005). The present study tests it as a mediator and moderator between study variables. This study is important for financial managers, policy makers and individual investors to comprehend the role of behavioural biases in financial decisions and financial satisfaction.

\section{Related literature}

\subsection{Financial self-efficacy and financial satisfaction}

Financial self-efficacy is defined as the confidence in one's capability in attaining absolute financial goals (Forbes \& Kara, 2010). It has a significant positive influence on individuals' financial behaviour and their outcomes (e.g., trading profit volatility, portfolio allocation, wealth accumulation, and financial satisfaction (Montford \& Goldsmith, 2016; Asebedo \& Payne, 2018). Studies reveal that positive financial behaviour and investment experience cause a reduction in financial stress and an increase in overall financial satisfaction level (Joo \& Grable, 2004). Individuals with a higher level of self-efficacy set higher goals, positively evaluate the task, consider external factors causing threats, and less inclined toward negative psychological factors such as anxiety depression, and stress (Bandura, 1999).

Besides this, another study reveals that women with higher self-efficiency tend to hold saving and investment products and avoid products related to debts (Farrell, Fry \& Risse, 2015). Besides its significance in decision making, FSE is also an imperative predictor of financial satisfaction. Asebedo and Payne, (2018) reveal that persons with a greater level of financial self-efficacy are better able to manage their financial anxiety and stress and such individuals are more pleased with their financial state. Based on the above discussion we hypothesized:

H1. Financial self-efficacy is positively related to financial satisfaction

\subsection{Reliance on expert and financial satisfaction}

The present study use "Reliance on expert" as a behavioural bias in Personal financial management where individuals make their decisions based on expert opinion with the view of their better expertise and knowledge. The study reveals that when individuals face difficulty in making financial decisions, they are more likely to follow the financial expert opinion (Gino \& Moore, 2007; Gino \& Schweitzer, 2008). Studies reveal that individuals with low-level of financial literacy seen to rely on an expert for investment decisions (Perry \& Morris, 2005). However, these individuals show a higher level of 
financial satisfaction (Xiao et al. 2006); Grable and Joo, 2001). Studies also show that ROE bias has a significant positive impact on financial satisfaction (Sahi, 2017). However, this study further elaborates that this relationship is not true, where investors have little investment experience however, where investors have enough investment experience this positive relationship exists. Based on the above discussion we hypothesized:

H2. Reliance on experts has a significant impact on financial satisfaction.

\subsection{Financial Socialisation and financial satisfaction}

Financial socialization is defined as the process through which individuals acquire knowledge, attitude, and behaviour which direct them toward satisfaction. (Hira et al., 2013). This process of socialization initiates at the infant level and endures throughout life (McNeal and Moschis, 1987). However, the level of socialization swerves from individual to individual which causes behavioural differences (Falahati and Paim, 2011). Many researchers disclose various contributors of financial socialization however, the prominent contributors are parents, peers, and media (Moschis, 1987; John, 1999; Falahati \& Paim, 2011; Starobin et al., 2013). Payne et al., (2014) noted that financial socialization has a significant impact on financial satisfaction. Saurabh and Nandan (2019) reveal that individuals rely on their family from the infant level and this affiliation influences their thinking process, attitude, and decision making especially in the matter of finance. They further conclude that individuals who perceive themselves as knowledgeable are also inclined by family, peers, and media toward their financial satisfaction. Based on the above discussion we hypothesized:

H3. Financial Socialization has a significant impact on financial satisfaction

\subsection{Mediating role of Speculative Risk}

Speculative Risk is defined as "the individual's inclination towards the risk-taking side" (Lampenius \& Zickar, 2005). This term is generally used as opposed to "risk aversion behaviour" and it shows individuals' gambling behaviour that how much amount of ambiguity that an investor is eager to take while making a financial decision (Hemrajani \& Sharma, 2018). Risk seeking or risk tolerance attitude is considered as an important ingredient of portfolio construction (Olsen, 2008). Corter and Chen (2006) state that individuals change risk attitudes that exists autonomously of their financial situations, and that these attitudes affect investment behaviour". Beside its role in financial decisions speculative risk is also considered as a predictor of financial satisfaction. Study reveals that Risk tolerance has a positive relationship with financial satisfaction (Joo \& Grable, 2004). In most of the studies, financial risk tolerance attitude acts as a mediator between certain variables. Study reveals that "the relationship between financial socialization and financial satisfaction with financial risk attitude as mediator were also found to be significantly positive" (Saurabh \& Nandan, 2019). Further, this study also reveals that financial risk attitude shows mediating between financial knowledge and financial satisfaction". Based on these arguments we hypothesized that: 
H4. Speculative risk mediates the relationship between financial self-efficacy and financial satisfaction.

H5. Speculative risk mediates the relationship between Reliance on experts and financial satisfaction.

H6. Speculative risk mediates the relationship between financial socialization and financial satisfaction.

\section{Research Methodology}

\subsection{Data and sample}

To perceive an individual's financial decision-making, the individual's having the "capacity to invest in the various instruments are of significant" (Gupta, 1991). The present study attracts the respondents having investment experience in different financial categories. These categories are fixed deposits, insurance, real estate, prize bond, and mutual funds. These categories were also used by Sahi, (2017) to observe the household behavioural biases and financial satisfaction. Structured questionnaire was distributed among above-mentioned people using the convenience sampling method. We distributed 250 questionnaires, and 230 people filled and returned the questionnaires. After scrutinizing of questionnaires 9 questionnaires were found incomplete so finally study used 221 questionnaires as a sample.

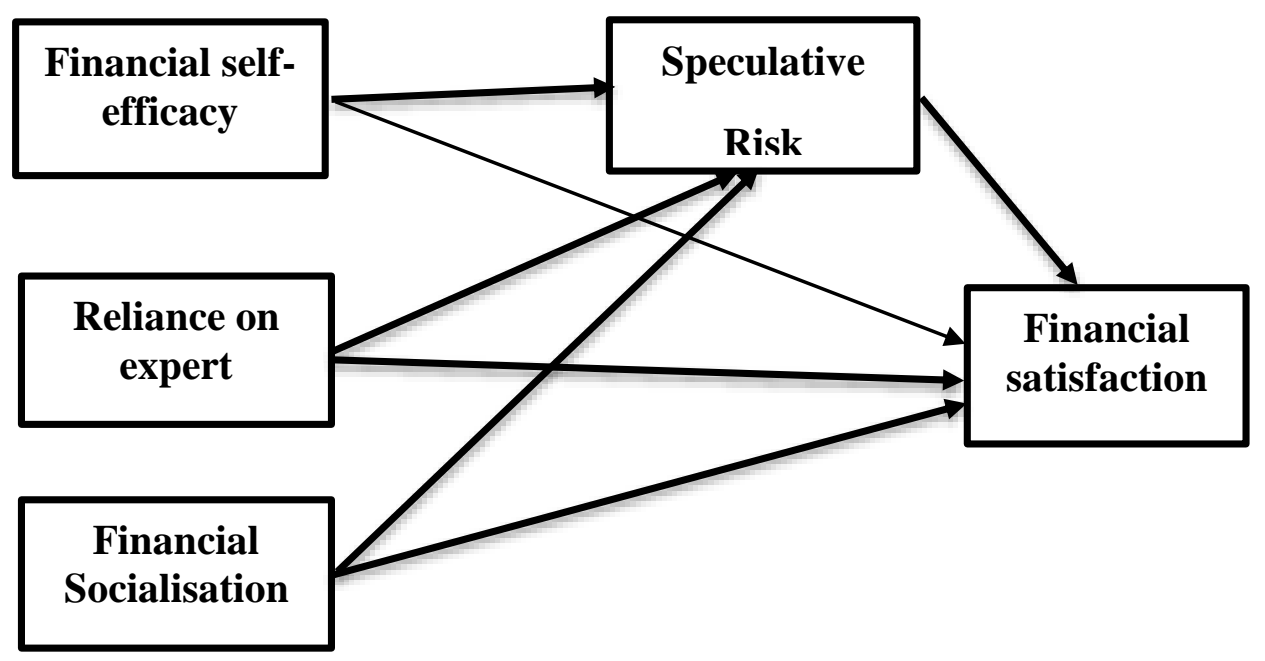

Figure 1. Conceptual framework

\subsection{Measurement}

Present study has five variables, three independents, one dependent, and one variable named speculative risk is test as mediator and as a moderator between IV's and DV. A structured questionnaire was used to measure these variables. Lown's (2011) Six-item financial self-efficacy scale is used to measure the financial self - efficacy of investors. 
Each question in this scale is rated on score 1 (exactly true) to 4 (not at all true). "Reliance on expert" of individuals was measured using the four-item scale developed and used by Sahi, (2017). Financial satisfaction was measured using six items developed by Hira and Mugenda (1998). These questions inquire about the individual's saving, their financial position, ability to meet contingencies, and their skills relevant to financial management. Besides this speculative risk was measured using 5 items. These items were taken from Mayfield et al. (2008) and Lampenius \& Zickar (2005) and used for this study with suitable modification. Along with this, the study also used a 6-item scale developed by Hira et al. (2013) to measure financial socialization.

\subsection{Statistical Analysis Techniques}

Study uses SPSS-20 and AMOS-20 software to conduct the data analysis. First we execute the reliability and validity test of the instrument, then we find the correlation between study variables. Besides this, the study uses SEM to test the proposed hypotheses.

\section{Analysis and Findings \\ 4.1 Reliability Analysis}

\begin{tabular}{|c|c|c|}
\hline \multicolumn{2}{|c}{ Table 1. Reliability Analysis } \\
\hline Constructs & No. of Items & Alpha \\
\hline Reliancial Self-Efficacy & 6 & .899 \\
\hline Financial Socialization & 4 & .886 \\
\hline Speculative Risk & 6 & .859 \\
\hline Financial Satisfaction & 5 & .870 \\
\hline
\end{tabular}

Table 1 shows the result of the reliability analysis. Study uses the Cronbach Alpha to check the reliability of scales. The result shows that the value of Cronbach Alpha for all constructs is greater than .70 which is highly acceptable. (Hair et al., 2010; Zaheer et al., 2008; Mishra and Shekhar, 2013).

\subsection{Construct validity}

To measure the construct validity study uses the convergent validity and discriminant validity parameters. Convergent validity is involved in measuring the "degree of correlation among different items that measure the same Construct" (Hair et al., 2010).

To test the convergent validity study finds Average variance extracted (AVE) and Scale Composite reliability (SCR). These were calculated by using the following formulas.

Table 2. Factor loadings, Validity and Reliability

\begin{tabular}{|l|l|l|l|l|}
\hline & \multicolumn{1}{|c|}{ Estimate } & \multicolumn{1}{|c|}{ AVE } & $\sqrt{\text { AVE }}$ & \multicolumn{1}{c|}{ CR } \\
\hline Financial Self -Efficacy & & .60 & .77 & .90 \\
\hline FSE1 & .899 & & & \\
\hline
\end{tabular}

Sukkur IBA Journal of Management and Business - SIJMB | Vol 8 No. 2 July - December 2021 @ Sukkur IBA University 


\begin{tabular}{|l|l|l|l|l|}
\hline FSE2 & .719 & & & \\
\hline FSE3 & .730 & & & \\
\hline FSE4 & .711 & & & \\
\hline FSE5 & .779 & & & \\
\hline FSE6 & .806 & & & \\
\hline Reliance on Expert & & .66 & .81 & .886 \\
\hline ROE1 & .818 & & & \\
\hline ROE2 & .840 & & & \\
\hline ROE3 & .785 & & & \\
\hline ROE4 & .811 & & & \\
\hline Financial Socialization & & .51 & .71 & .86 \\
\hline FSO1 & .739 & & & \\
\hline FSO2 & .784 & & & \\
\hline FSO3 & .717 & & & \\
\hline FSO4 & .653 & & & \\
\hline FSO5 & .642 & & & \\
\hline FSO6 & .745 & & & \\
\hline Speculative Risk & & .58 & .76 & .87 \\
\hline SR1 & .883 & & & \\
\hline SR2 & .844 & & & \\
\hline SR3 & .762 & & & \\
\hline SR4 & .680 & & & \\
\hline SR5 & .629 & & & \\
\hline Financial Satisfaction & & .58 & .76 & \\
\hline FS1 & .891 & & & \\
\hline FS3 & .732 & & & \\
\hline FS5 & .743 & & & \\
\hline FS6 & .650 & & & \\
\hline & & & & \\
\hline
\end{tabular}

Average variance extracted $=\frac{\text { Sum of squared factor loadings }}{\text { Number of indicators }}$

Scale composite reliability $=\left(\frac{(\Sigma \text { factor loading })^{2}}{\left(\left(\sum \text { factor loading }\right)^{2}+\sum(1-(\text { factor loading }))^{2}\right)}\right.$

Table 2 result revealed that the factor loading for each item is greater than 0.60 , and the value of Scale composite reliability is greater than 0.70 and the value of AVE is greater than 0.50 which reveals that study items hold sufficient convergent validity. The findings also determined an adequate value of discriminant validity for all the factors as suggested by Hair et al. (2010) that "the value of discriminant validity should be above $0.70 "$ ". 
Table 3. Correlation Coefficient.

\begin{tabular}{|l|c|c|c|c|c|}
\hline Construct & FSE & ROA & FSO & FS & SR \\
\hline Financial Self efficacy & 1 & .035 & .045 & $.162^{*}$ & .120 \\
\hline Reliance on Experts & & 1 & $.161^{*}$ & $.237^{* *}$ & -.043 \\
\hline Financial Socialization & & & 1 & $.142^{*}$ & $.375^{* *}$ \\
\hline Financial Satisfaction & & & & 1 & $.283^{* *}$ \\
\hline Speculative Risk & & & & & 1 \\
\hline
\end{tabular}

*. Correlation is significant at the 0.05 level (2-tailed).

**. Correlation is significant at the 0.01 level (2-tailed).

Study run the Pearson correlation test using SPSS to find the relationship between study variables. These results find that financial self-efficacy, reliance on experts, and financial socialization has a significant positive relationship with financial satisfaction. Besides this financial socialization has a significant positive relationship with speculative risk.

\subsection{Common method Bias}

CMB is arising when we collect the data from similar respondents at the same time (Podsakoff and Organ 1986). This data is also collected from similar respondents at the same time so there may be a common method Bias. To check this Harmon's one-factor test is performed in SPSS. The result shows that first factor only explains $19 \%$ variance which is far away from $50 \%$, so there is no problem of CMB.

The Structure equation model technique was used to analyze the impact of independent variables (Financial Self-efficacy, financial socialization and Reliance on experts) on the dependent variable (Financial Satisfaction). Figure 2 shown this relationship and revealed that financial Self-efficacy and reliance on experts has significant positive impact on the financial satisfaction level of the investors. Where financial socialization has no significant influence on financial satisfaction. Table 4 reveals that an increase in 1 level of financial self-efficacy caused an increase of $22 \%$ in financial satisfaction. These results are consistent with Asebedo \& Payne (2018) which revealed "Financial self-efficacy is an important predictor of financial satisfaction". Beside this an increase of 1 level of reliance on experts caused an increase of $27 \%$ in financial satisfaction. These results are consistent with literature which reveals that rational information during the investment decision-making cause wealth maximization and increases satisfaction level (Rashid \& Nishat ,2009); Waqar et al., 2017).

\section{Structural model for testing the impact of IV's on DV}




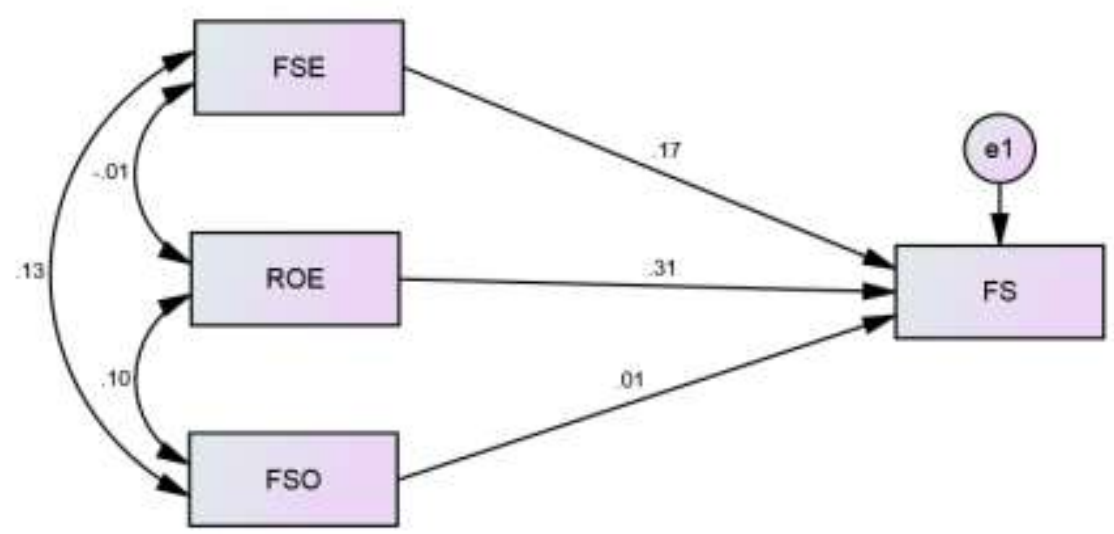

Figure 2. Structural Model.

Table 4. Regression Weights

\begin{tabular}{|l|l|l|l|l|l|}
\hline Variables & Estimate & S.E. & C.R. & P & Accept/Reject \\
\hline FS <--- FSE & .221 & .080 & 2.754 & .006 & Accepted \\
\hline FS <--- ROE & .277 & .056 & 4.956 & $* * *$ & Accepted \\
\hline FS <--- FSO & .008 & .075 & .114 & .909 & Rejected \\
\hline
\end{tabular}

\section{Structural Model 2(Mediation Test)}

To test the mediation analysis, we run the structural model using AMOS. The mediation model is shown in Figure 3. Study finds acceptable model fit (Table 5) as Chi-square value is 6.351 with $\mathrm{Df} 3, \mathrm{GFI}=.989, \mathrm{AGFI}=.944, \mathrm{NFI}=.924$ as per the reference of Hair et al. (2010).

Table 5. Model Fit Indices of the constructs

\begin{tabular}{|c|l|l|l|l|l|l|}
\hline$X^{2}$ & Df & $X^{2} / \mathrm{df}$ & RMR & CFI & GFI & AGFI \\
\hline 6.351 & 3 & 2.117 & .038 & .956 & .989 & .944 \\
\hline
\end{tabular}

Table 6 indicates the result of mediation analysis. These results reveal that the direct impact of financial self-efficacy on financial satisfaction remains significant but reduces in frequency which indicates that Speculative risk partially mediates the relation between these variables. Besides this, financial socialization shows no impact on financial satisfaction, so we do not proceed with further steps. The second column shows that the direct impact of Reliance on experts on financial satisfaction remains significant but reduces in frequency which indicates that speculative risk partially mediates the relationship between these variables. 


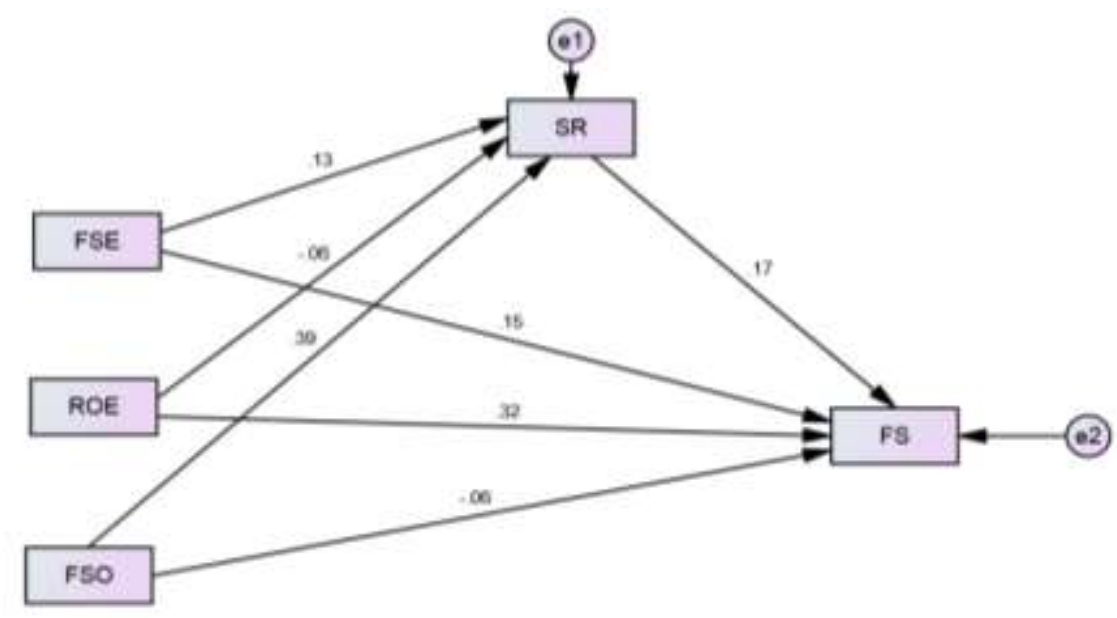

Figure 3. Structural Model.

Table 6. Hypotheses testing (with mediation)

\begin{tabular}{|l|l|l|l|l|l|l|l|}
\hline Hypothesis & $\begin{array}{l}\text { Direct } \\
\text { Effect }\end{array}$ & $\mathbf{p}$ & $\begin{array}{c}\text { Indirect } \\
\text { Effect }\end{array}$ & $\mathbf{p}$ & $\begin{array}{c}\text { Total } \\
\text { Effect }\end{array}$ & $\mathbf{p}$ & Result \\
\hline $\begin{array}{l}\mathrm{FSE} \rightarrow \mathrm{SR} \\
\mathrm{FS}\end{array}$ & .193 & 0.028 & 0.028 & 0.037 & .221 & 0.097 & $\begin{array}{l}\text { Partial } \\
\text { Mediation }\end{array}$ \\
\hline $\begin{array}{l}\mathrm{ROE} \\
\mathrm{FS}\end{array}$ & .286 & 0.00 & -0.009 & 0.003 & .277 & 0.006 & $\begin{array}{l}\text { Partial } \\
\text { Mediation }\end{array}$ \\
\hline
\end{tabular}

The figure 4 model is run to check the moderating role of Speculative risk between financial self-efficacy and financial satisfaction. The result in table 7 shows that Speculative risk does not moderate the relationship between FSE and FS ( $\beta=0.060$, p $>0.05)$.

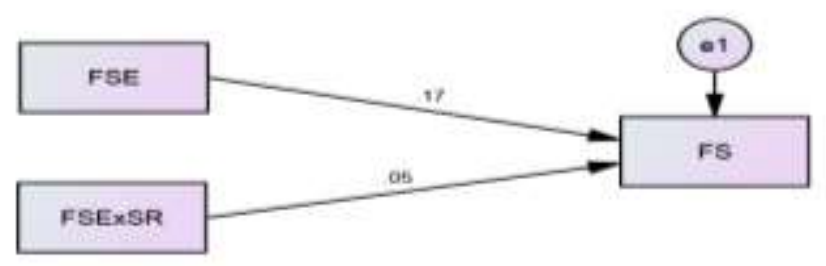

Figure 4. Structural Model. 
Table 7. Hypotheses testing (with Moderation).

\begin{tabular}{|lll|ccccc|}
\hline & & & & Estimate & S.E. & C.R. & P \\
\hline FS & $<---$ & FSE & .218 & .084 & 2.594 & .009 \\
FS & $<---$ & FSE $\times$ SR & .049 & & .063 & .785 & $\underline{.432}$ \\
\hline
\end{tabular}

\section{Structural Model 4 (Moderation Test 2)}

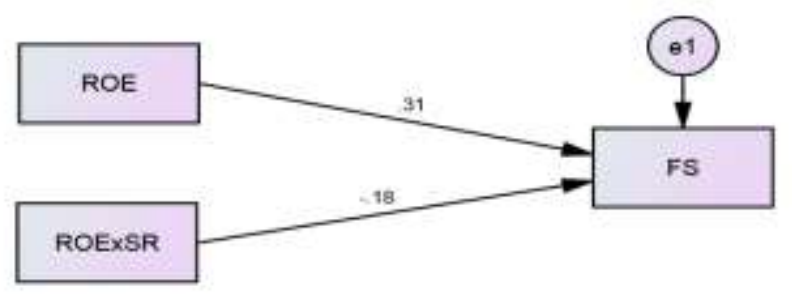

Figure 5. Structural Model.

The figure 5 model is run to check the moderating role of Speculative risk between Reliance on expert bias and financial satisfaction. The result in table 8 shows that Speculative risk significantly moderates the relationship between ROE and FS ( $\beta=$ $.145, \mathrm{p}<0.05)$.

Table 8. Hypotheses testing (with Moderation).

\begin{tabular}{|lll|lccc|}
\hline & & & Estimate & S.E. & C.R. & P \\
\hline FS & $<---$ & ROE & .275 & .055 & 4.961 & $* * *$ \\
FS & $<---$ & ROExSR & -.170 & .059 & -2.862 & .004 \\
\hline
\end{tabular}

\section{Structural Model 5 (Moderation Test 3)}




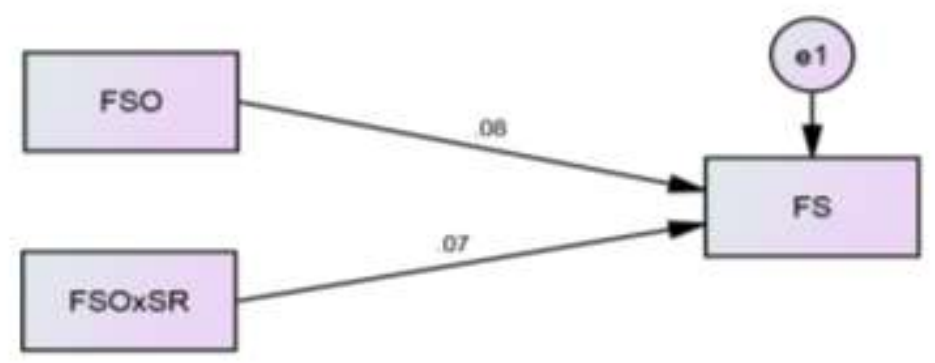

Figure 6. Structural Model.

Table 9. Hypotheses testing (with Moderation).

\begin{tabular}{|lll|lllc|}
\hline \multicolumn{2}{|c|}{ Variables } & Estimate & S.E. & C.R. & P \\
\hline FS & $<---$ & FSO & .099 & .078 & 1.265 & .206 \\
FS & $<---$ & FSO $\times$ SR & .068 & .062 & 1.109 & .267 \\
\hline
\end{tabular}

The figure 5 model is run to check the moderating role of Speculative risk between Financial Socialization and financial satisfaction. The result in the table shows that Speculative risk does not moderate the relationship between FSO and FS ( $\beta=.091, p>$ $0.05)$.

\section{Discussion and Conclusion}

This study is designed to examine the impact of behavioural biases on perceived financial satisfaction and to determine the role of Speculative Risk between these variables. Using a structured questionnaire, the study collects the data from respondents and then analyzes the same by using Reliability Analysis, Factor Analysis, and Structural Equation Modeling (SEM) with the help of SPSS and AMOS. The result of the study discloses that financial self-efficacy and Reliance on expert has significant effect on financial satisfaction, while financial socialization has no significant effect on financial satisfaction. Besides this, the study reveals that Speculative risk partially mediates the relationship of financial self-efficacy and reliance on experts with financial satisfaction. Besides this, the moderating role of speculative risk was observed between IV's and DV's. The study reveals that speculative risk significantly moderates the relationship of Reliance on experts and financial satisfaction. These results are consistent with existing literature (Sahi, 2017; Hira et al., 2013; Asebedo \& Payne, 2018). This study is important for financial managers, policymakers, and individual investors to comprehend the role of behavioural biases in financial decisions and financial satisfaction. 


\subsection{Contribution and future research direction}

This study contributes to the literature on behavioural finance by explaining the relationship between behavioural biases and financial satisfaction. This study reveals that biases are not always bad, and these biases play an important role in financial decisions. Future studies can use other behavioural biases such as overconfidence, selfcontrol bias, socially responsible investing bias, and adaptive tendency in relation to financial satisfaction. Besides this, they can also comprehend the role of financial literacy in explaining the financial satisfaction of individual investors.

\section{Author's Contribution:}

Muhammad Nauman Sadiq: Conceptualization, Methodology, Writing-Original Draft, Formal Analysis,

Syed Ali Raza Hamid: Review and Editing, Supervision

Raja Ased Azad Khan: Data collection, Review and Editing

\section{Data Availability Statement:}

The data collected and examined during the current study is available on request from corresponding author.

\section{Conflict of Interest:}

No conflict of interest

\section{Funding:}

No funding is received for this research project.

\section{References}

Asebedo, S., \& Payne, P. (2019). Market volatility and financial satisfaction: The role of financial self-efficacy. Journal of Behavioral Finance, 20(1), 42-52.

Atkinson, A. \& Messy, F. A. (2011). Assessing financial literacy in 12 countries: An OECD/INFE international pilot exercise. Journal of Pension Economics and Finance, 10(4), 657-665.

Farrell, L., Fry, T. R., \& Risse, L. (2016). The significance of financial self-efficacy in explaining women's personal finance behaviour. Journal of Economic Psychology, 54, 85-99.

Folkman, S., \& Lazarus, R. S. (1980). An analysis of coping in a middle- aged community sample. Journal of Personality and Social Psychology, 21, 219-239.

Forbes, J. \& Kara, S. M. (2010) Confidence mediates how investment knowledge influences investing self-efficacy. Journal of Economic Psychology, 31, 435-443.

Hair, J.F., Blach, W.C., Babin, B.J. and Anderson, R.E. (2010) Multivariate Data Analysis, Pearson Publication, Harlow.

Hira, T.K. and Mugenda, O. (2000), "Gender differences in financial perceptions, behaviors and satisfaction", Journal of Financial Planning-Denver, Vol. 13 No. 2, pp. 86-92. 
Hira, T.K., Sabri, M.F. and Loibl, C. (2013) 'Financial socialization's impact on investment orientation and household net worth', International Journal of Consumer Studies, Vol. 37, No. 1, pp.29-35.

Howard, J. A. (2012). Behavioral Finance: Contributions of Cognitive Psychology and Neuroscience to Decision Making. Journal of Organizational Psychology, 12(3), 52-70.

Kumar Saurabh, Tanuj Nandan, (2018) "Role of financial risk attitude and financial behavior as mediators in financial satisfaction: Empirical evidence from India", South Asian Journal of Business Studies, https://doi.org/10.1108/SAJBS-07-2017-0088

Lampenius, N., \& Zickar, M. J. (2005). 'Development and Validation of a model and measure of Financial Risk- Taking'. The Journal of Behavioural Finance. 6(3):129-143

Lown, J. M. "Development and Validation of a Financial Selfefficacy Scale." Journal of Financial Counseling and Planning, 22, (2011), pp. 54-63.

Mayfield, C., Perdue, G., \& Wooten, K. (2008). Investment management and personality type. Financial Services Review, 17(3), 219-237.

Mishra, P.K. and Shekhar, B.R. (2013) 'Consumer behavior, customer satisfaction vis-à-vis brand performance: an empirical study of dairy food supply chain in India', International Journal of Indian Culture and Business Management, Vol. 7, No. 3, pp.399-412.

Montford, W., \& Goldsmith, R. E. (2016). How gender and financial self-efficacy influence investment risk taking. International Journal of Consumer Studies, 40(1), 101-106.

Otuteye, E., \& Siddiquee, M. (2014). Overcoming Cognitive Biases: A Heuristic for Making Value Investing Decisions. The Journal of Behavioral Finance, 16(2), 140-149.

Pellerone, M. (2014). Interpersonal adjustment, personal resources, aptitudes, and interests: vocational decision-making process in a group of Italian adolescents. US-China Education Review A \& B 4, 648-655.

Pellerone, M. (2015). Influence of identity, congruence of interest and coping strategy on decision making. Journal of Procedia - Social and Behavioral Sciences, 191, 1344-1348. Doi: 10.1016/j.sbspro.2015.04.465

Perry, V. G., \& Morris, M. D. (2005). Who is in control? The role of selfperception, knowledge, and income in explaining consumer financial behaviour. Journal of Consumer Affairs, 39, 299-313.

Rashid, M., \& Nishat, A. (2009). Satisfaction of retail investors on the structural e_ciency of the market: Evidence from a developing country context. The Asian Academy of Management Journal, 14 (2), 41-64.

Sarah Asebedo \& Patrick Payne (2018): Market Volatility and Financial Satisfaction: The Role of Financial Self-Efficacy, Journal of Behavioral Finance, DOI: 10.1080/15427560.2018.1434655

Saurabh, K. and Nandan, T. (2019) 'Role of financial knowledge, financial socialisation and financial risk attitude in financial satisfaction of Indian individuals', Int. J. Indian Culture and Business Management, Vol. 18, No. 1, pp.104-122.

Shalini Kalra Sahi, Ashok Pratap Arora \& Nand Dhameja (2013) An Exploratory Inquiry into the Psychological Biases in Financial Investment Behavior, Journal of Behavioral Finance, 14:2, 94-103, DOI: 10.1080/15427560.2013.790387

Sahi, S.K. (2013), "Demographic and socio-economic determinants of financial satisfaction: a study of SEC-A segment of individual investors in India", International Journal of Social Economics, Vol. 40 No. 2, pp. 127-150.

Sahi, S.K. (2017), "Psychological biases of individual investors and financial satisfaction", Journal of Consumer Behaviour, Vol. 16 No. 6, pp. 511-535.

Sukkur IBA Journal of Management and Business - SIJMB | Vol 8 No. 2 July - December 2021 @ Sukkur IBA University 
Muhammad Nauman Sadiq et. al. Behavioural biases in Personal Financial Management and Perceived Financial

Sarah Asebedo \& Patrick Payne (2018): Market Volatility and Financial Satisfaction: The Role of Financial Self-Efficacy, Journal of Behavioral Finance, DOI: $10.1080 / 15427560.2018 .1434655$

Shim, S., Xiao, J.J., Barber, B.L. and Lyons, A.C. (2009) 'Pathways to life success: a conceptual model of financial well-being for young adults', Journal of Applied Developmental Psychology, Vol. 30, No. 6, pp.708-723.

Xiao, J. J., Sorhaindo, B., \& Garman, E. T. (2006). Financial behaviours of consumers in credit counseling. International Journal of Consumer Studies, 30, 108-121.

Zaheer, A., Rehman, K., \& Saif, M. I. (2008). Development and testing of a business process e_ciency scale. European Journal of Social Sciences, 7 (2), 179-188. 